\title{
Gênese e evolução do saprólito no planalto de Campos do Jordão: implicações na evolução do relevo
}

\author{
May Christine Modenesi-Gauttieri', Maria Cristina Motta de Toledo², \\ Lélia Cristina da Rocha Soares ${ }^{3}$, Fabio Taioli ${ }^{3} \&$ Hélio Shimada $^{1}$
}

\begin{abstract}
Resumo Resultados de análises geoquímicas, mineralógicas e micromorfológicas de seis perfis completos do saprólito, amostrados por sondagem nos níveis escalonados do planalto de Campos do Jordão, permitiram identificar (1) tendências de intemperismo normais para clima tropical a subtropical e (2) diferenças entre a evolução observada nos materiais superficiais $(<1 \mathrm{~m})$ e nos materiais de sondagem. Condições iniciais de gibbsitização direta, registradas na parte superior do saprólito e preservadas no topo dos morros acima de 1800 $\mathrm{m}$, foram seguidas por condições de laterização menos agressivas, registradas nos materiais dos testemunhos, de intemperismo mais recente, por processos de monossialitização. Portanto, durante todo o processo de evolução do manto teria havido permanência da mesma tendência geral laterítica, com duas fases de diferente intensidade, alitização e monossialitização, resultantes de ajuste às modificações ambientais que acompanharam a elevação gradual do planalto. A tendência à podzolização observada nos solos das áreas mais elevadas provavelmente reflete as condições ambientais criadas pelo soerguimento a altitudes em torno de $2000 \mathrm{~m}$. Os grandes traços da evolução do relevo e formação do manto de intemperismo do planalto de Campos do Jordão parecem acompanhar, de modo geral, as fases tectônicas reconhecidas no segmento central do rifte do Paraíba do Sul.
\end{abstract}

Palavras-chave: intemperismo profundo, intemperismo laterítico, alitização, monossialitização, evolução do relevo.

\begin{abstract}
Genesis and evolution of the saprolite in the Campos do Jordão plateau: implications in landscape evolution. Geochemical, mineralogical, morphological and micromorphological analyses of six complete profiles of the saprolite sampled by drilling in the stepped levels of the Campos do Jordão Plateau show (1) weathering tendencies normal in tropical and subtropical climates and (2) differences between the evolution of superficial $(<1 \mathrm{~m})$ and drill-core materials. Initial conditions of direct gibbsitization, registered in the upper part of the saprolite and preserved on hilltops above $1800 \mathrm{~m}$, were followed by less agressive lateritization conditions, registered in drill core materials, of more recent weathering, by monosialitization processes. Thus, a general lateritic trend with two phases of different intensity - alitization and monosialitization - persisted during the entire process of mantle formation. Alitization and monosialitization are interpreted as adjustments to environmental changes following the gradual uplift of the plateau. The tendency towards podzolization, evident in soils of the highest hilltops, probably reflects environmental conditions existing after the plateau uplift to about $2000 \mathrm{~m}$. The schematic model of the Campos do Jordão landscape evolution and mantle formation is broadly consistent with tectonic phases recognized in the central segment of the neighboring Paraiba do Sul rift valley.
\end{abstract}

Keywords: deep weathering, lateritic weathering, alitization, monosialitization, landscape evolution.

INTRODUÇÃO O manto de intemperismo pode conter registros de alterações pretéritas que refletem a influência das condições ambientais e a intensidade de evolução dos materiais. O estudo mineralógico, micromorfológico e geoquímico de perfis completos do saprólito tem por objetivo investigar a evolução do manto de intemperismo nos níveis escalonados do planalto de Campos do Jordão (Modenesi 19881, 1988 b) . Os dados ora obtidos a partir de amostras das zonas mais profundas dos perfis de alteração foram complementados por dados anteriores sobre os solos e a parte superior do saprólito (Modenesi 1980, 1983).
O planalto de Campos do Jordão localiza-se na borda sudeste do bloco principal da Mantiqueira (Fig. 1), delimitado por dois sistemas de falhas transcorrentes de direção geral NE (Hasui et al. 1978), Jundiuvira e Paiol Grande, de idade pré-cambriana e eopaleozóica, reativados no Terciário. Biotita granitos, biotita gnaisses bandados, biotita xistos, quartzitos, rochas calciossilicáticas e anfibolitos, além de metassedimentos de uma pequena bacia sedimentar neoproterozóica, constituem as principais litologias do planalto (Hasui et al. 1978, DNPM 1979, Morais et al. 1998).

O estudo do manto de intemperismo foi realiza-

1 - Instituto Geológico, Secretaria do Meio Ambiente, São Paulo (SP) Brasil. E-mail: maymodenesi@igeologico.sp.gov.br,

hshimada@igeologico.sp.gov.br

2 - Universidade de São Paulo, Instituto de Geociências e Escola de Artes, Ciências e Humanidades - EACH, São Paulo (SP), Brasil.

E-mail: mcristol@usp.br

3 - Universidade de São Paulo, Instituto de Geociências, São Paulo (SP), Brasil. E-mail: leliajuvinter@hotmail.com; ftaioli@usp.br 

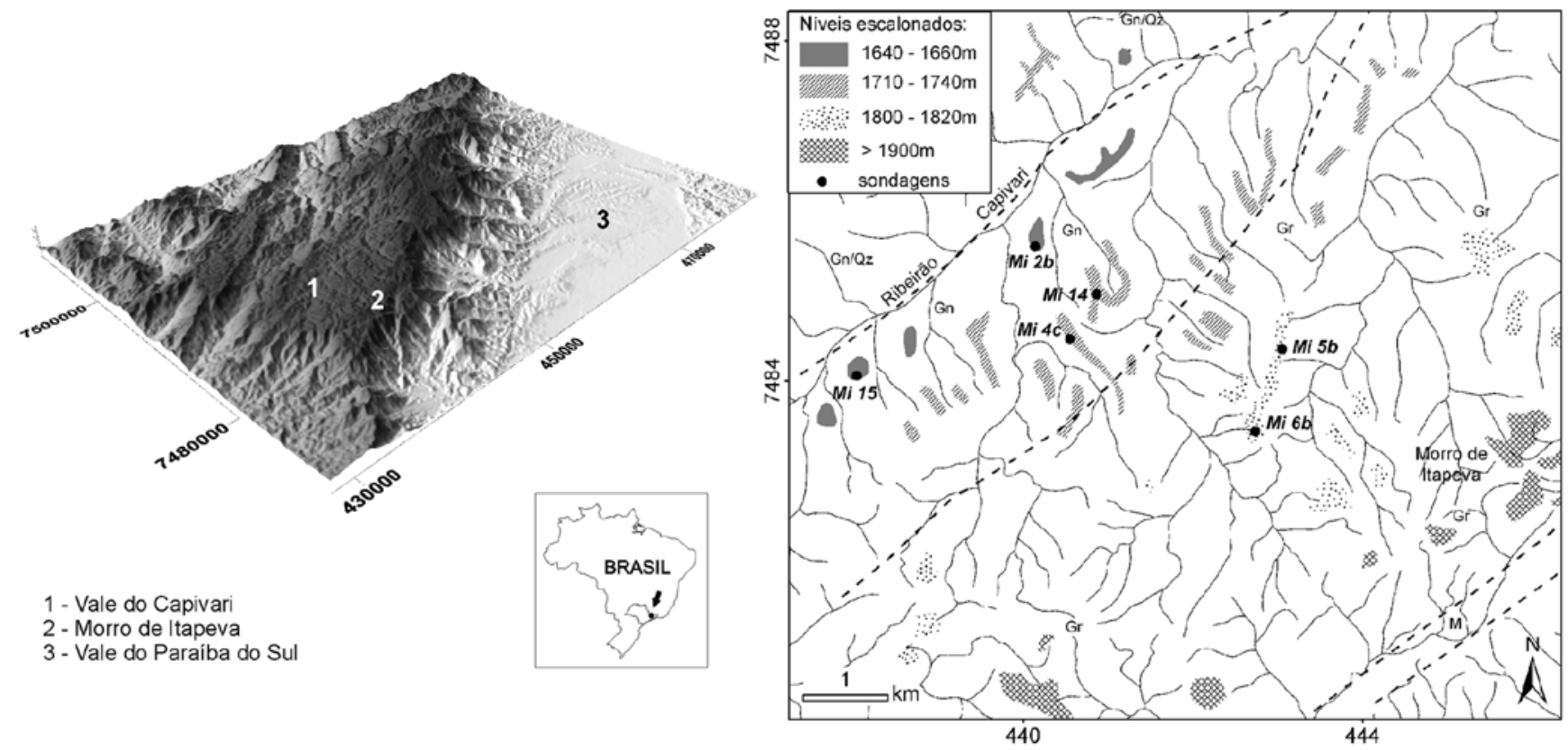

Figura 1 - Localização do planalto de Campos do Jordão, níveis escalonados e locais de sondagem. Litologia: $\mathrm{Gn} / \mathrm{Qz}$ (gnaisses e quartzitos), Gn (gnaisses finamente bandados, com intercalações de quartzitos e xistos), Gr (granitóides e gnaisses localmente bandados) e M (metassedimentos). Os contatos litológicos coincidem com as falhas principais (linha interrompida).

do entre a borda sudeste do planalto e o vale do Capivari, onde os interflúvios têm seus topos nivelados a altitudes que decrescem do divisor da Mantiqueira (1900/1950 m) para norte e noroeste, em três níveis escalonados a 1800/20 m, 1710/40 m e 1640/60 m (Fig. 1). Nesta área predominam rochas gnáissicas com orientação NE-SW e ENE-WSW e mergulhos acima de $50^{\circ}$. Biotita gnaisses finamente bandados (bandas centimétricas), com intercalações quartzíticas e xistosas, ocorrem nos dois níveis topográficos inferiores. Acima de $1800 / 20 \mathrm{~m}$, os gnaisses apresentam porções com bandamento menos definido (decimétrico a métrico), de composição quartzo-feldspática, por vezes porfiroblásticos. É comum a ocorrência de bolsões pegmatíticos métricos.

O objetivo do estudo de perfis completos, desenvolvidos in situ no planalto de Campos do Jordão, foi reconstituir a evolução do intemperismo pelo estudo das filiações minerais e das modificações das estruturas originais, assim como do comportamento geoquímico dos elementos, em termos de sua eliminação na drenagem ou retenção em fases minerais resistentes, transformadas ou neoformadas. Tais informações registram os efeitos do intemperismo químico e são importantes indicadores dos caminhos da alteração e de suas relações com as condições ambientais. Formação ou não de argilominerais e alteromorfos às expensas dos minerais primários, retenção ou eliminação de elementos químicos liberados pela desestabilização dos minerais iniciais, com as neoformações correspondentes, e processos de re-estruturação característicos da pedogênese, com suas estruturas específicas, são essenciais para o entendimento dessas relações e explicam a importância do estudo micromorfológico na metodologia de pesquisa.

O conhecimento detalhado do manto de intemperismo, de sua gênese e evolução, e o estabelecimento das relações entre intemperismo profundo e relevo tem como objetivo final aperfeiçoar o modelo de evolução do planalto desenvolvido anteriormente (Modenesi 1988 a, 1988 b, Modenesi-Gauttieri 2000, ModenesiGauttieri et al. 2002).

MATERIAIS E MÉTODOS Os procedimentos adotados incluem estudos de campo, com observação dos materiais in situ, reconhecimento dos tipos litológicos e dos níveis topográficos e escolha dos locais para a execução das sondagens, feitas sempre em locais próximos aos já estudados (Modenesi 1980, 1983), para possibilitar a correlação das amostras dos testemunhos com aquelas recuperadas anteriormente. Estes trabalhos se apoiaram em mapeamentos geológicos 1: 250.000 do planalto de Campos do Jordão (Hasui et al. 1978, DNPM 1979, Morais et al. 1998).

Tentativas de reconhecimento da espessura do manto e topografia da frente de intemperismo por aplicação do método de eletro-resistividade não tiveram sucesso, em razão de interferências relacionadas à ocupação urbana (Taioli et al. 2005).

Sondagens mecânicas foram feitas nos três níveis escalonados do planalto (duas perfurações por nível), utilizando sonda rotativa de acionamento hidráulico - com barrilete duplo livre de $1,5 \mathrm{~m}$ de comprimento e diâmetro interno de $58,7 \mathrm{~mm}$; os furos até a rocha sã foram todos verticais. A descrição dos testemunhos teve início a aproximadamente $1 \mathrm{~m}$ de profundidade, uma vez 
que a parte superior dos perfis é quase sempre constituída por materiais artificiais (aterros ou revestimentos), ou foi decapitada pelos trabalhos de instalação das máquinas. A caracterização da parte superior dos perfis baseouse em dados anteriores de um grande número de perfis de formações superficiais (Modenesi 1980, 1983) amostradas nos mesmos locais das sondagens; trinta das lâminas delgadas então analisadas foram descritas novamente, segundo os critérios da pesquisa atual.

Oitenta e sete amostras representativas das diferentes fácies de alteração reconhecidas nos testemunhos foram selecionadas para as análises em laboratório.

A análise granulométrica foi feita com secagem à temperatura ambiente, desagregação e eliminação da fração superior a $2 \mathrm{~mm}$ e sifonagem da suspensão do material disperso com pirofosfato de sódio; as frações areia e silte foram determinadas por peneiramento a seco.

O estudo mineralógico, em amostras totais moídas a 200 mesh, baseou-se na identificação dos minerais por difração de raios-X (DRX), integrada com análises macroscópicas e micromorfológicas por microscopia óptica (MO) e, em algumas amostras, eletrônica de varredura (MEV-EDS) aplicada na identificação de fases muito finas, não reconhecíveis ao MO.

Para o estudo micromorfológico, as amostras duras foram laminadas de modo convencional; fragmentos selecionados das amostras friáveis foram impregnados com resina, para confecção das lâminas delgadas. A MEV foi realizada nas próprias lâminas, ou em pequenos fragmentos naturais, montados em suportes e recobertos por material condutor (carbono ou ouro).

No estudo micromorfológico foram considerados os minerais primários e secundários e todas as suas feições de alteração e de instalação. Este procedimento permitiu - mais do que a simples identificação das fases presentes nos diferentes horizontes do manto intempérico - evidenciar feições indicativas de relações genéticas entre as fases e de intensidade da alteração intempérica, possibilitando interpretações sobre a evolução dos processos de intemperismo. Dados micromorfológicos sobre a alteração dos minerais primários, transferência de materiais dentro dos perfis e reorganização pedogenética crescente serviram de base para diferenciar as principais etapas de intemperismo, inclusive o início da evolução pedogenética. A terminologia usada é baseada em Brewer (1964), Bisdom (1967) e Delvigne (1998).

Análises químicas totais por fluorescência de raios-X (FRX) foram feitas nas amostras (moídas a 200 mesh) de cada testemunho de sondagem, para elementos maiores, P e Ti. A escolha das amostras levou em consideração a heterogeneidade da composição mineralógica dos materiais alterados, em termos de tipos litológicos da rocha de origem dos perfis. Valores de perda ao fogo (PF) foram obtidos por gravimetria. Análises térmicas diferenciais (ATD) e gravimétricas (TG), empregadas para definir as características térmicas dos materiais e a perda de massa por aquecimento, não acrescentaram dados significativos à presente pesquisa; nenhuma nova identificação de mineral resultou dessas análises. Os procedimentos de preparação e analíticos foram efetuados nos laboratórios do Instituto de Geociências da USP.

\section{PERFIS E SUCESSÃO VERTICAL DE FÁCIES} DE INTEMPERISMO Nos três níveis escalonados, entre o morro de Itapeva e o vale do ribeirão Capivari, a espessura do manto de intemperismo varia de aproximadamente $30 \mathrm{~m}$ a mais de $50 \mathrm{~m}$ (Fig. 2). É maior nos gnaisses finamente bandados dos morros mais baixos (1640-60 m) e diminui sucessivamente nos gnaisses bandados do nível intermediário $(1710-40 \mathrm{~m})$ e nos gnaisses graníticos localmente bandados dos morros mais elevados (1800-1820 m).

Os testemunhos de sondagem A recuperação dos testemunhos foi melhor nos materiais desenvolvidos a partir de rochas com predominância de minerais que se alteram em argilominerais, como feldspato e minerais micáceos, uma vez que os materiais das intercalações quartzíticas ocorrem completamente desagregados, inviabilizando a recuperação. A descrição dos testemunhos de sondagem (dois perfis-tipo para cada nível topográfico do planalto) levou em conta as variações de cor e textura dos materiais de alteração, sua semelhança com a rocha subjacente e a sucessão vertical das fácies de alteração: (1) rocha sã (quando presente), (2) rocha alterada pouco friável, (3) isalterita - rocha alterada friável, com estrutura primária ainda conservada, (4) aloterita - rocha alterada sem conservação da estrutura e (5) solo. Isalterita e aloterita, bem como materiais de características transicionais, constituem o saprólito e indicam, respectivamente, conservação ou não das estruturas, fato confirmado pela análise micromorfológica posterior.

Os seis perfis estudados, com a sucessão vertical de fácies de intemperismo, estão representados de forma esquemática na figura 2. A análise dos materiais de um dos perfis amostrados a 1640-60m (Mi 15) foi prejudicada pela recuperação muito baixa.

A grande heterogeneidade das características petrográficas (quantidade e distribuição de quartzo e minerais micáceos) e estruturais (espessura e mergulho do bandamento) dos gnaisses do planalto condiciona a percolação das águas de infiltração, determinando um comportamento irregular da seqüência de intemperismo ao longo dos perfis, com aparecimento de descontinuidades ou inversões; em conseqüência, materiais menos evoluídos do ponto de vista do intemperismo podem ocorrer acima de outros mais intensamente intemperizados. Este fato evidenciou certas peculiaridades de comportamento dos materiais intemperizados, que se distanciam de produtos provenientes do intemperismo de rochas homogêneas.

De modo geral, o teor de argila varia com a profundidade (Tab. 1 e Fig. 3), com tendência irregular de aumento da base para o topo dos perfis. Constitui exceção o perfil Mi-15 (1640/60 m) que apresenta diminuição do teor em argila; no entanto, como neste perfil não houve recuperação suficiente de material, estes resultados não devem ser considerados. Em Mi-14 (1710/40 m) a quantidade de argila permanece praticamente a mesma. Portanto, a sequência normal de intemperismo, caracte- 

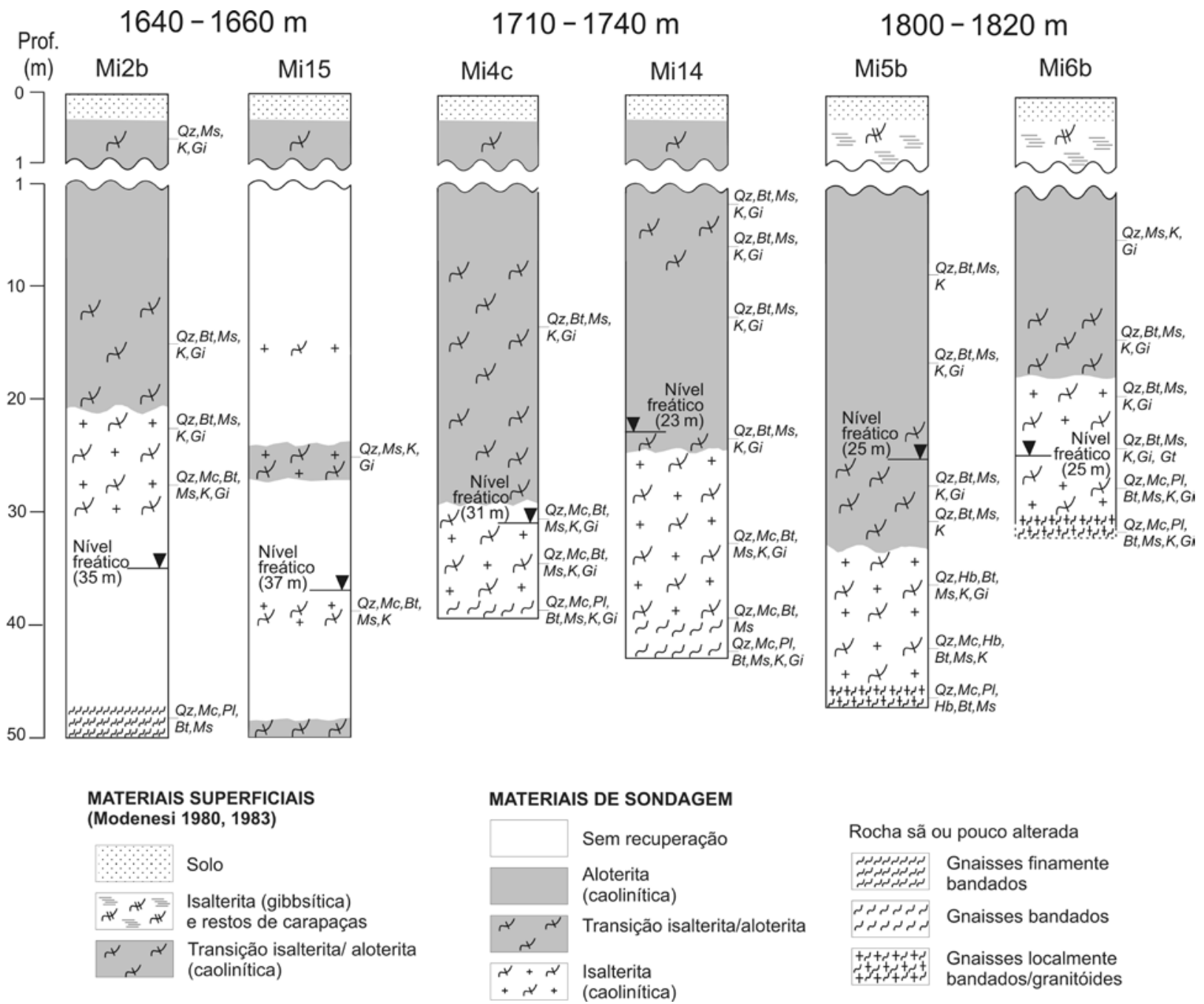

Figura 2 - Perfis esquemáticos compostos, incluindo materiais superficiais e de sondagem, nos níveis escalonados do planalto, com sucessão de fácies de intemperismo e composição mineral.

rizada por aumento linear de argila com a evolução do processo, não aparece de forma nítida nos perfis estudados. Na maioria dos casos, a sucessão de materiais mais argilosos ou arenosos, corresponde, respectivamente, à alteração das bandas mais micáceas ou quartzosas dos gnaisses da área; a quantidade de argila reflete mais a heterogeneidade litológica do que o grau de intemperismo, aumentando nas amostras originalmente mais micáceas.

A parte superior do saprólito e os solos A caracterização dos solos e da parte superior do saprólito (0-1 m) efetuada anteriormente (Modenesi 1980, 1983) é aqui sintetizada para completar a descrição dos perfis de sondagem.

Até aproximadamente $1 \mathrm{~m}$ de profundidade, a rocha alterada é caracterizada por grandes variações de coesão e cor; geralmente avermelhada, pode apresentar cores claras acima de $1800 \mathrm{~m}$ ou, abaixo desta altitude, em condições de hidromorfia. As estruturas, quase sempre preservadas, podem desaparecer em bolsões descontínuos. Os solos dos níveis escalonados do planalto são rasos $(10,30$ e até $50 \mathrm{~cm})$, com linha de seixos basal, no contato com a rocha muito alterada; foram classificados por Oliveira et al. (1975) como litossolos ou solos com B incipiente pouco espesso e horizontesA friáveis, de cor preta ou bruno-escura.

Nos morros mais elevados (aproximadamente, a $1800 \mathrm{~m}$ e $1930 \mathrm{~m}$ ), restos de antigas carapaças alúmino-ferruginosas - in situ e como blocos em linhas de seixos - de composição mineralógica semelhante, representam o último estádio de evolução das rochas do planalto. Acima de $1900 \mathrm{~m}$ as carapaças são pouco densas, rugosas, escoriáceas, ferruginizadas em superfície, e podem apresentar pequenos alvéolos milimétricos preenchidos por crostas de gibbsita; nas rochas orientadas as estruturas estão bem preservadas, mas em granitóides os vestígios da estrutura original persistem apenas nas microestruturas. As carapaças dos morros de $1800 \mathrm{~m}$ são mais densas e têm sempre preservada a estrutura original, com alvéolos geralmente preenchidos por argila vermelha.

MINERALOGIA E MICROMORFOLOGIA DO MANTO DE INTEMPERISMO No estudo da disposição espacial dos minerais, em escala microscópi- 
Tabela 1 - Distribuição percentual das frações granulométricas argila, silte e areia em amostras dos perfis estudados.

Nível topográfico $1640 / 60 \mathrm{~m}$ (perfis Mi2b e Mi15)

\begin{tabular}{c|c|c|c|c|c|c|c|c|c}
\hline $\begin{array}{c}\text { Mi2b } \\
\text { Amostra }\end{array}$ & prof. (m) & Argila (\%) & Silte (\%) & Areia (\%) & $\begin{array}{c}\text { Mi15 } \\
\text { Amostra }\end{array}$ & prof. (m) & Argila (\%) & Silte (\%) & Areia (\%) \\
\hline LS2 & 44,5 & 1,2 & 17,0 & 81,9 & LS68 & 49 & 22,0 & 32,6 & 38,8 \\
\hline LS5 & 29,4 & 21,5 & 18,2 & 61,6 & LS70 & 41 & 2,2 & 23,3 & 73,7 \\
\hline LS7 & 23,0 & 6,2 & 54,4 & 42,4 & LS72 & 34 & 2,2 & 16,9 & 81,0 \\
\hline LS10 & 3,5 & 8,1 & 52,7 & 41,8 & LS75 & 23,9 & 2,6 & 20,5 & 77,2 \\
\hline
\end{tabular}

Nível topográfico 1710/40m (perfis Mi4c e Mi14)

\begin{tabular}{|c|c|c|c|c|c|c|c|c|c|}
\hline $\begin{array}{c}\text { Mi4c } \\
\text { Amostra }\end{array}$ & prof. (m) & Argila (\%) & Silte $(\%)$ & Areia (\%) & $\begin{array}{c}\text { Mi14 } \\
\text { Amostra } \\
\end{array}$ & prof. (m) & Argila (\%) & Silte (\%) & Areia (\%) \\
\hline LS29 & 27,0 & 17,5 & 29,6 & 54,6 & LS57 & 24,0 & 21,1 & 39,6 & 29,1 \\
\hline LS30 & 17,0 & 11,6 & 43,5 & 35,1 & LS59 & 21,3 & 9,6 & 42,9 & 48,3 \\
\hline LS32 & 1,5 & 59,0 & 11,0 & 28,6 & LS61 & 16,0 & 34,8 & 49,2 & 19,5 \\
\hline & & & & & LS63 & 10,5 & 21,4 & 49,0 & 32,2 \\
\hline & & & & & LS67 & 0,1 & 14,2 & 33,8 & 53,8 \\
\hline
\end{tabular}

Nível topográfico 1800/20m (perfis Mi6b e Mi5b)

\begin{tabular}{|c|c|c|c|c|c|c|c|c|c|}
\hline $\begin{array}{c}\text { Mi6b } \\
\text { Amostra }\end{array}$ & prof. (m) & Argila (\%) & Silte $(\%)$ & Areia (\%) & $\begin{array}{c}\text { Mi5b } \\
\text { Amostra }\end{array}$ & prof. (m) & Argila (\%) & Silte $(\%)$ & Areia (\%) \\
\hline LS16 & 16,0 & 4,2 & 18,8 & 76,4 & LS36 & 42,2 & 2,3 & 18,3 & 78,5 \\
\hline LS18 & 8,0 & 7,2 & 30,0 & 64,1 & LS40 & 35 & 11,1 & 19,1 & 68,2 \\
\hline \multirow[t]{5}{*}{ LS22 } & 0,3 & 14,0 & 38,6 & 47,6 & LS43 & 23,0 & 14,8 & 40,9 & 45,2 \\
\hline & & & & & LS44 & 21,0 & 4,9 & 21,4 & 73,1 \\
\hline & & & & & LS45 & 18,0 & 5,0 & 38,7 & 57,0 \\
\hline & & & & & LS50 & 3,5 & 10,3 & 52,1 & 39,0 \\
\hline & & & & & LS51 & 1,5 & 43,9 & 27,8 & 27,8 \\
\hline
\end{tabular}

(Determinações efetuadas no Instituto de Geociências, USP, pelo método da pipetagem, para as frações argila e silte, e por peneiramento, para a fração areia).
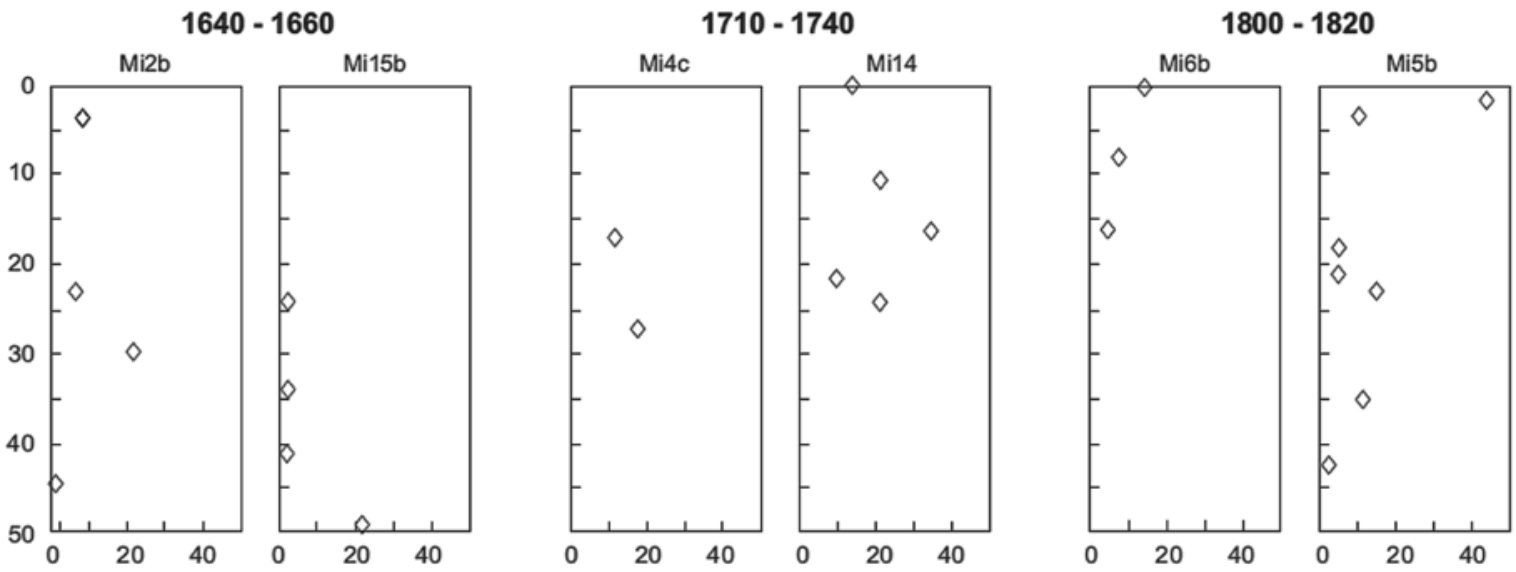

Figura 3 - Distribuição percentual da fração argila em amostras dos perfis estudados, mostrando que o seu aumento da base para o topo não é observado em todos os casos, o que foi relacionado à heterogeneidade litológica e à impossibilidade de comparação direta entre os materiais.

ca, algumas das feições evidenciadas foram descritas e utilizadas nas interpretações. A dissolução de mineral primário com formação de material secundário amor- fo indica pobreza de lixiviação dos produtos dissolvidos na hidrólise dos minerais e pode indicar situação de drenagem pobre geral (posição topográfica baixa ou 
material pouco permeável) ou local (microssistemas de alteração fechados).

A formação de minerais supérgenos associada à alteração de minerais primários significa grau mais avançado de lixiviação do que a formação de produtos amorfos; no entanto, mesmo que haja a formação de minerais - com cristalização de fases, portanto - , deve-se ainda identificar o tipo de mineral formado, para possibilitar a interpretação do ambiente de origem do tipo de intemperismo, ou seja, situações de alitização, mono ou bissialitização.

A ocorrência de alteromorfos (minerais secundários organizados em plasma primário) completos pode ser tomada como indicativa de constância das condições de intemperismo e falta de fenômenos posteriores de destruição desta feição, como, por exemplo, superposição de outras condições de intemperismo ou de fenômenos de pedogênese. As feições de iluviação são indicativas de mobilização de íons dissolvidos e precipitação em zonas de circulação.

Os testemunhos de sondagem A composição mineral das amostras totais dos testemunhos recuperados nos três níveis topográficos é, em linhas gerais, semelhante àquela dos solos e parte superior da rocha alterada (Modenesi 1980, 1983), incluindo minerais primários resistentes, como quartzo e muscovita e, em menor quantidade, biotita, além dos minerais secundários caolinita, gibbsita e produtos ferruginosos e fases identificadas pelas diversas técnicas (Fig. 2).

A alteração do feldspato (plagioclásio e microclínio) se inicia já na base dos perfis, com formação restrita e fugaz de material amorfo ao longo das descontinuidades dos cristais (Fig. 4 a e b); plagioclásio é o primeiro a desaparecer, microclínio pode persistir um pouco além da base, em relíquias parcialmente alteradas. Caolinita ocorre desde a base dos perfis em plasma secundário, entre grãos do esqueleto de minerais resistentes (quartzo, abundante, e muscovita, mais rara); embora não sejam encontradas relações genéticas diretas evidentes (alteromorfos) entre caolinita e feldspato, sua origem pode ser deduzida da situação espacial, pois, nas porções quartzo-feldspáticas da rocha, forma a matriz argilosa caolinítica entre os grãos de quartzo, mais resistentes. Alteromorfos perfeitos de gibbsita são raros e incompletos; essas feições são muito mais completas, evidentes e abundantes nas amostras da parte superior do saprólito (Fig. 5) (Modenesi 1980, 1983).

Assim como o feldspato, os minerais micáceos também se alteram segundo a ordem natural, sendo a muscovita bem mais resistente. No entanto, ao contrário do feldspato, a alteração das micas forma minerais supérgenos em alteromorfos. Biotita gera alteromorfos com caolinita, destacados por linhas de produtos ferruginosos nos antigos espaços interlamelares (Fig. 4 c); a muscovita também, mas geralmente sem produtos ferruginosos (Fig. 4 d). Caolinita e gibbsita neoformadas ocorrem em descontinuidades dos alteromorfos micáceos (Fig. 4 e), como resultado de transporte em solução de alumínio e sílica. Estes últimos aparecem até a parte intermediária dos perfis, mas são normalmente menos comuns, já em vias de desorganização, na sua parte superior. Constitui exceção o perfil Mi2b (1640/60 m), com alteromorfos completos e bem preservados em porções mais rasas (até $12 \mathrm{~m}$ ). Alteromorfos de muscovita parecem mais resistentes que os de biotita, pois persistem na parte superior dos perfis (Fig. 4 f). Com a evolução do processo formam-se massas argilosas sem preservação da geometria dos cristais feldspáticos originais; a ocorrência de alteromorfos é rara.

Magnetita tem alteração irregular, pode estar alterada já na base dos perfis ou resistir até a sua parte superior; no entorno dos grãos a alteração às vezes forma goethita bem cristalizada (Fig. 4 g).

O quartzo é abundante, mas irregularmente distribuído devido à heterogeneidade litológica; mostra sinais de dissolução já na base dos perfis (Fig. 4 h), mas persiste até o topo. Em algumas amostras dos testemunhos de todos os níveis topográficos, grãos de quartzo fraturados e parcialmente dissolvidos podem apresentar neoformação de gibbsita em descontinuidades intra e intercristalinas (Fig. 4 i e j).

Quanto aos minerais supérgenos, gibbsita ocorre ao longo de todos os perfis, mas nem sempre na sua base, em rocha pouco alterada. A única exceção é o perfil Mi5 b (1800-1820 m) que não apresenta gibbsita na parte superior, fato provavelmente relacionado à ocorrência de zona mais quartzosa ou muito micácea, na qual o feldspato, predecessor usual da gibbsita, é mais escasso.

Caolinita, presente em todas as amostras, nem sempre aparece como primeira fase de alteração, sendo geralmente precedida por materiais amorfos; pode ocorrer em cristais bem formados, típicos de neoformação (Fig. 4 k). Filossilicatos interestratificados ocorrem subordinadamente na fração argila de algumas amostras da parte basal e intermediária dos perfis. Produtos ferruginosos (goethita, hematita), cristalizados ou não, estão presentes em todos os materiais analisados.

Plasma secundário, dominado por argiliplasma, ocorre em porções restritas da isalterita e aumenta de importância na transição isalterita/aloterita. Constituído principalmente por material ferruginoso, caolinítico e gibbsítico, é mais ferruginoso se caolinítico, pois a caolinita associa-se de forma mais estreita aos produtos ferruginosos (Fig. 4 1).

$\mathrm{O}$ agrupamento das amostras segundo a semelhança das feições micromorfológicas permitiu confirmar a diferenciação de fácies de alteração dos testemunhos (Fig. 2) e reconhecer cinco principais etapas de intemperismo: (1) dissolução inicial de mineral primário, (2) formação de mineral secundário associado à alteração de mineral primário, (3) ocorrência de alteromorfos (plasma primário) completos, (4) feições de iluviação (plasma secundário) independentes da alteração dos minerais vizinhos, (5) fundo matricial do solo com estrutura porfirosquélica. As três primeiras etapas correspondem à alteração dos minerais primários, a quarta indica evolução mais intensa de intemperismo, com remobilização de materiais, e a última, reorganização pedogenética, que não chega a estágios mais evoluídos. 

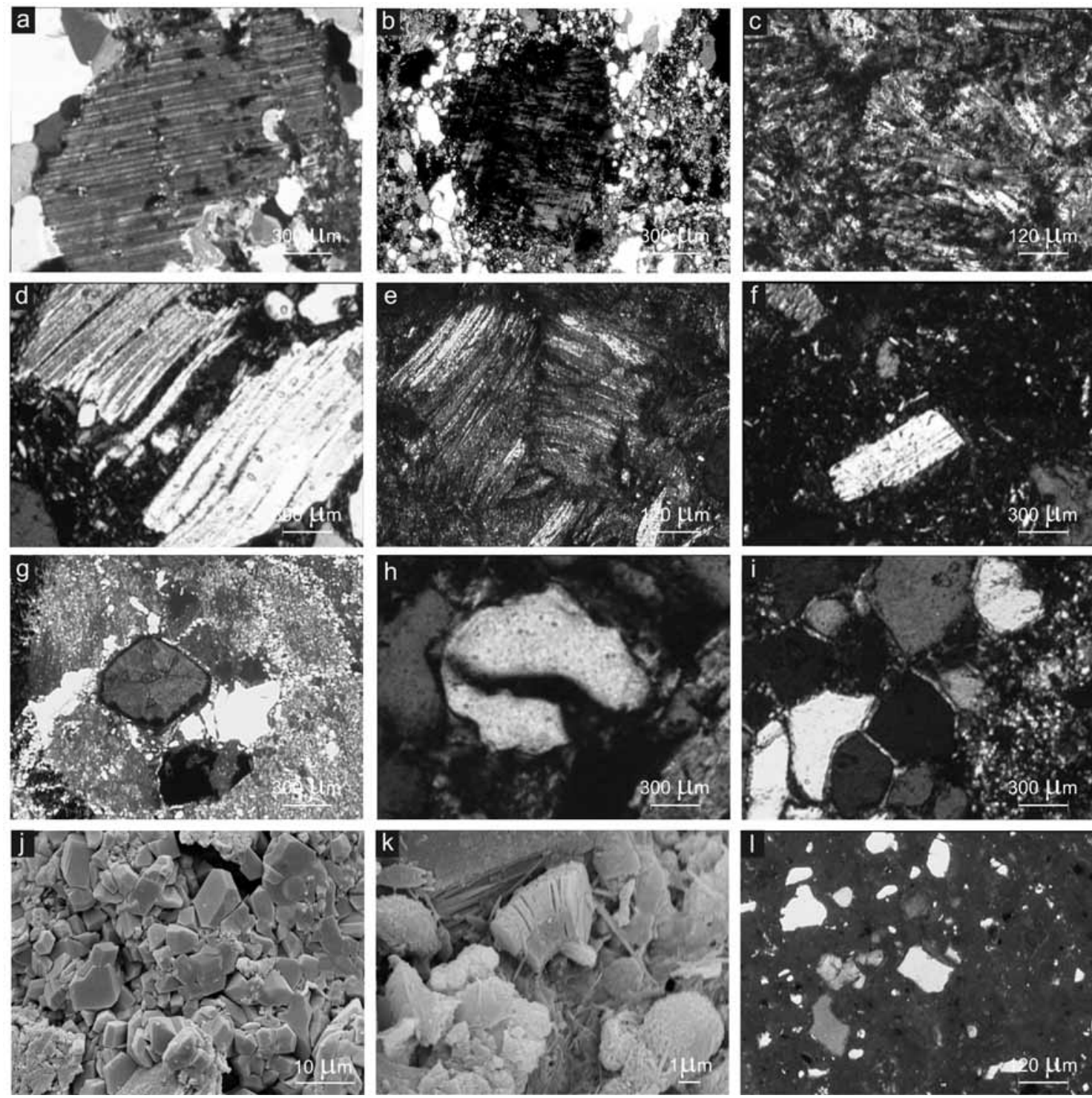

Figura 4 - Fotomicrografias mostrando as principais feições micromorfológicas utilizadas para as interpretações. (a) Plagioclásio e (b) microclínio em início de intemperismo, mostrando a formação de produtos amorfos, isótropos, de composição sílico-aluminosa, em algumas descontinuidades dos cristais; nivel topográfico 1800/1820 m; (c) alteromorfo a partir de biotita, formado por caolinita e oxihidróxidos de ferro; nível topográfico 1710/1740 m; (d) alteromorfo a partir de muscovita, parcialmente intemperizada em caolinita; nivel topográfico 1800/1820 m; (e) caolinita e gibbsita entre as lamelas de alteromorfos caoliniticos provenientes de biotita, também com produtos ferruginosos nas descontinuidades; nivel topográfico 1800/1820 m; (f) aloterita com alteromorfo caolinítico de muscovita; nivel topográfico 1800/1820 m; (g) alteromorfo de magnetita; nivel topográfico 1710/1740 m; (h) dissolução de quartzo; nivel topográfico 1640/1660 m; (i) gibbsita neoformada nas descontinuidades de quartzo parcialmente dissolvido; nível topográfico 1710/1740 m; (j) gibbsita neoformada, em cristais tabulares; nivel topográfico 1640/1660 m; (k) caolinita neoformada em cristais tipo "acordeon"; nivel topográfico 1640/1660 m; (l) plasma secundário caolinítico escurecido por produtos ferruginosos, entre grãos de esqueleto de quartzo e muscovita, em estrutura porfirosquélica; nivel topográfico 1710/1740 m. (a) a (i) e (l), fotos ao microscópio óptico, nícois cruzados; (j) e (k), imagens ao microscópio eletrônico de varredura.

Nos materiais aloteríticos de todos os testemunhos de sondagem, já com sinais de re-estruturação do tipo pedoplasmação e início de formação de estruturas pedológicas, há predominância da estrutura porfirosquélica (Fig. 4 1); nesta, típica de menor evolução intempéri- ca, grãos de esqueleto permanecem rodeados por plasma secundário, com certa porosidade irregularmente distribuída. Praticamente não ocorre estrutura aglomeroplásmica, característica de etapa mais intensa de reorganização pedogenética, rumo à formação de agregados e de- 

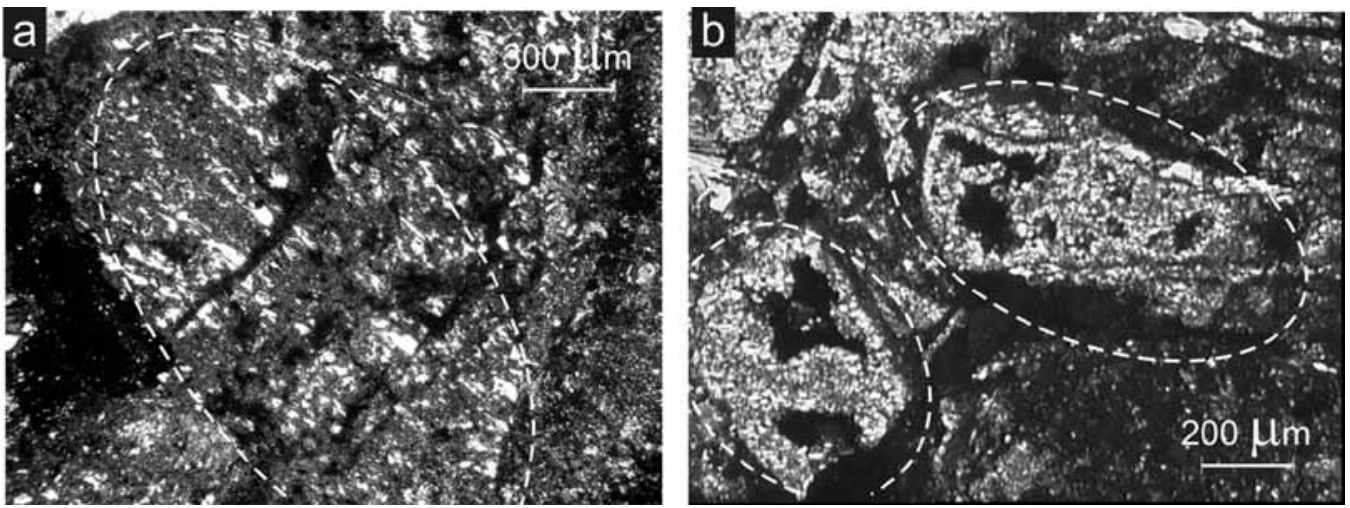

Figura 5 - Gibbsitização direta de feldspato nos materiais de superficie, mostrando a diferença fundamental ali encontrada em relação aos materiais de sondagem. (a) Alteração direta incompleta, com relíquias de feldspato (porções brancas) em meio ao plasma primário gibbsítico (parte cinza, microcristalina); (b) alteromorfos completos de gibbsita, proveniente de feldspato. Fotos ao microscópio óptico, nícois cruzados.

mais feições pedológicas resultantes da pedoplasmação.

A parte superior do saprólito e os solos Segundo trabalhos anteriores (Modenesi 1980, 1983), a rocha alterada constitui material muito intemperizado, com predominância de gibbsita; caolinita predomina apenas nos morros de 1710-40 m. Quartzo e muscovita são os principais minerais residuais. Anfibólio, plagioclásio e minerais opacos podem ocorrer nos morros de 1800-20 m; nos dois níveis mais baixos sericita e epídoto são freqüentes.

A alteração do feldspato é caracterizada por gibbsitização; caolinita ocorre apenas em fase inicial de intemperismo e, algumas vezes, nos morros de 1710-1740 $\mathrm{m}$.

O quartzo está sempre relativamente bem preservado, mesmo em presença de gibbsitização acentuada.

Tendência à caolinização dos minerais micáceos esboça-se aos $1800 \mathrm{~m}$ e intensifica-se com a diminuição da altitude. A alteração da muscovita é caracterizada por caolinização parcial; gibbsitização foi observada apenas nas carapaças da borda dos topos. Acima de $1900 \mathrm{~m}$ há gibsitização da biotita, caolinita aparece apenas em materiais pouco evoluídos; em altitudes menores biotita altera-se em alteromorfos de caolinita, com freqüentes inclusões de gibbsita. Sericita ocorre intacta ou parcialmente caolinizada.

Argilominerais 2:1 (vermiculita aluminosa) aparecem na alteração incipiente de rochas granitóides.

Oxihidróxidos de ferro ocorrem em alteromorfos de minerais ferromagnesianos e como impregnações dispersas no material de alteração.

Fenômenos de remobilização e reorganização da gibbsita são generalizados, com exceção apenas da rocha alterada a $1640-60 \mathrm{~m}$.

Nas carapaças encontradas acima de 1800 m, a gibbsita é comum em alteromorfos de feldspato e minerais micáceos ou em matriz de granulação variada, com eventuais concentrações esparsas (nódulos, filões e geodos). Biotita tem as suas antigas lamelas defor- madas pela neogênese de óxidos de ferro e de gibbsita, com destruição da forma das micas. $O$ único mineral residual é o quartzo, conservado ou fraturado, com preenchimento de gibbsita e/ou ferro. Reorganização do ferro, com preenchimento de fissuras, revestimento de vazios e formação de massas ferro-argilosas zonadas é típica desses materiais e implica em maior porosidade e alteração da rocha. Há nítida predominância de gibbsita. Ausência de minerais residuais além do quartzo e fenômenos característicos de remobilização do ferro atestam sua intensa evolução.

A fração mineral dos solos é formada essencialmente por quartzo, caolinita e gibbsita. $\mathrm{O}$ teor de argila aumenta com a diminuição da altitude, refletindo o substrato dos níveis mais baixos, gnaisses ricos em micas e pobres em quartzo. Na fração argila, caolinita e gibbsita são os principais minerais secundários; gibbsita pode predominar acima de $1900 \mathrm{~m}$, caolinita e minerais interestratificados (vermiculita aluminosa) são mais freqüentes abaixo de $1800 \mathrm{~m}$. Na fração silte, os principais minerais são quartzo e gibbsita.

Resultados do estudo da parte superior dos perfis de intemperismo (Modenesi 1980, 1983) evidenciam variações do tipo de evolução geoquímica e grau de intemperismo dos solos e parte superior do saprólito. Nos dois níveis topográficos inferiores, melhor conservação dos minerais micáceos e importância relativa da caolinita indicariam menor grau de evolução na parte superficial do saprólito. Acima de 1800 m, a importância da gibbsita no saprólito define uma tendência geral à alitização; abaixo dessa altitude, o aumento de caolinita evidencia a predominância de processos de monossialitização. Esses processos foram interpretados como diferentes graus de intemperismo dentro de uma mesma tendência geral à laterização. Carapaças e latossolos encontrados no planalto testemunhariam fase pretérita de alteração laterítica, relacionada a climas tropicais úmidos ou sub-úmidos, mais quentes do que o atual clima de altitude (Modenesi 1980, 1983). 
Tendência à podzolização, ajustada às recentes condições de temperatura e umidade, foi reconhecida nos solos situados acima de $1800 \mathrm{~m}$ (Modenesi 1980, 1983), fato assinalado anteriormente por Oliveira et al. (1975) no Parque Estadual de Campos do Jordão.

CARACTERÍSTICAS GEOQUÍMICAS DAS AMOSTRAS DOS TESTEMUNHOS Os dados de composição química das amostras (Tab. 2) indicam, para todos os perfis, da base para o topo, a seguinte situação: $\mathrm{Si}$ diminui, $\mathrm{Al}$ aumenta, $\mathrm{Fe}$ varia pouco, elementos alcalinos $(\mathrm{Na}$ e $\mathrm{K})$ e alcalino-terrosos $(\mathrm{Ca}$ e $\mathrm{Mg}$ ) diminuem abruptamente e depois se mantêm em teores muito baixos; P e Ti mantêm-se aproximadamente constantes. Eventuais discordâncias refletem a heterogeneidade da rocha (por exemplo, amostras mais quartzosas entre outras menos quartzosas) ou associação com minerais acessórios, como é provavelmente o caso do Ti e do P, em que irregularidade de distribuição pode influenciar o comportamento desses elementos ao longo do perfil.

A tentativa de cálculo do balanço geoquímico isovolume, aplicada aos setores isalteríticos não teve sucesso, em razão da heterogeneidade litológica, com variação (centimétrica a métrica) das características granulométricas, da espessura das bandas gnáissicas e das proporções relativas dos minerais principais (quartzo, biotita, feldspato potássico e plagioclásio). Neste caso, a comparação entre amostras subseqüentes foi inviabilizada pela diversidade dos materiais. Mesmo assim, os valores de densidade aparente (D.A.) ilustram a perda de massa promovida pelo intemperismo (Tab. 3 e Fig. 6) para a sequência de amostras isalteríticas de cada perfil. As variações dessa tendência geral também podem ser creditadas à heterogeneidade da rocha inicial.

\section{EVOLUÇÃO DO MANTO DE INTEMPERIS-}

MO O estudo geoquímico, mineralógico e micromorfológico dos testemunhos de sondagem de Campos do Jordão levou a considerações sobre a evolução dos minerais e da composição química do manto de intemperismo nos três níveis escalonados do planalto. Todos os perfis refletem a heterogeneidade do material de origem; a variação dos gnaisses que predominam no planalto, com zonas mais quartzosas ou mais micáceas, gera por intemperismo materiais ora mais ricos em quartzo e menos argilosos, ora menos quartzosos e mais ricos em argilominerais. Tais variações litológicas ocorrem em todas as direções, inclusive na vertical, e condicionam a percolação das águas, controlando a progressão do intemperismo. A facilidade de infiltração intensifica o intemperismo em determinadas zonas dos perfis, perturbando a seqüência normal esperada e explicando a sucessão vertical, nem sempre linear, da intensidade de alteração. Da mesma forma, a variação dos teores de elementos maiores, encontrada nas análises químicas, não reflete apenas o comportamento geoquímico normal dos elementos no processo de intemperismo, mas também a variação geoquímica original das amostras. $\mathrm{O}$ aumento não linear do teor em argila da base para o topo dos perfis (Fig. 3) expressa as mesmas variações.
Nos testemunhos de sondagem, ou seja, abaixo dos materiais estudados anteriormente, as relações espaciais entre minerais primários e supérgenos, indicadoras de relações de gênese, puderam ser observadas claramente apenas para os minerais micáceos. Biotita $\mathrm{e}$ muscovita formam alteromorfos caoliníticos, por transformação mineralógica, havendo também neoformação de caolinita e de gibbsita nos alteromorfos, neste caso, sem possibilidade de se estabelecer uma relação direta de filiação entre os minerais micáceos iniciais e as neoformações mencionadas, já que os íons envolvidos podem ter sido transportados em solução. No caso da alteração da biotita, é comum a ocorrência de produtos ferruginosos nos espaços interlamelares.

Já as relações de gênese observadas nos materiais mais superficiais (Modenesi 1980, 1983), de modo geral semelhantes ao observado nos testemunhos, diferem em alguns aspectos. Acima de 1900 m, gibbsitização direta de biotita é evidenciada pela manutenção das estruturas primárias em alteromorfos. Alteromorfos de feldspato, raros nos materiais dos testemunhos, ocorrem na parte superior da rocha alterada. Nas amostras dos testemunhos é frequente a alteração inicial de microclínio e plagioclásio em material amorfo, isótropo ao MO.

A alteração do feldspato e dos minerais micáceos evidencia, portanto, diferenças marcantes entre os materiais da parte superior dos perfis de alteração e dos testemunhos, ou seja, a alteração direta em gibbsita (gerando alteromorfos), indicativa de condições mais agressivas de intemperismo, é típica dos primeiros, mais antigos. Gibbsita não alteromórfica poderia resultar de dessilicificação da caolinita em locais ou épocas sem condições para transformação direta.

As tendências de evolução geoquímica e mineralógica observadas nos testemunhos são, em geral, normais, sem descontinuidades, exceção apenas do maior truncamento dos perfis situados nas colinas mais baixas (1640-60 m). Nenhuma relação foi encontrada entre a posição atual do lençol freático e o zoneamento da alteração ao longo dos perfis.

Em resumo, os materiais de superfície resultam de fase de alitização distinta da fase de monossialitização posterior que produziu os materiais dos testemunhos. Os materiais de sondagem registram, em todos os níveis topográficos, a profundidades superiores a $1 \mathrm{~m}$, evidências de intemperismo também laterítico, porém menos intenso, caracterizado por predominância de caolinita, produto de menor perda de sílica (monossialitização) do que a verificada na fase de alteração anterior. Esta monossialitização é caracterizada por formação de material caolinítico em plasma secundário (proveniente da caolinização do feldspato, que pode ou não passar por fase de material amorfo e, praticamente, não resulta em alteromorfos reconhecíveis) e pela formação de alteromorfos caoliníticos a partir dos minerais micáceos. Note-se que os materiais gibbsíticos superficiais não podem ser considerados produtos da evolução dos materiais caoliníticos (por dessilicificação), pois não seria possível haver formação inicial de material caolinítico, com pobre preservação das estruturas, e, depois, este material ser 
Tabela 2 - Composição química dos perfis em elementos maiores, $\mathrm{P}$ e Ti (\% em peso dos óxidos) e perda ao fogo $\left(\mathrm{H}_{2} \mathrm{O}\right)$.

Nível topográfico 1640/60m (perfis Mi2b e Mi15)

\begin{tabular}{c|c|c|c|c|c|}
\hline Perfil & Mi2b & & & & \\
\hline Amostra & 1 & 5 & 6 & 8 & 10 \\
\hline Prof. (m) & 48 & 30 & 26,3 & 19 & 3,5 \\
\hline $\mathrm{SiO}_{2}$ & 61,6 & 60,7 & 56,4 & 57,9 & 53,1 \\
\hline $\mathrm{Al}_{2} \mathrm{O}_{3}$ & 17,5 & 17,5 & 21,6 & 23,9 & 25,9 \\
\hline $\mathrm{Fe}_{2} \mathrm{O}_{3}$ & 5,7 & 9,1 & 9,3 & 6,2 & 7,3 \\
\hline $\mathrm{CaO}$ & 3,5 & 0,6 & 0,6 & 0,6 & 0,6 \\
\hline $\mathrm{MgO}$ & 2,3 & 1,6 & 0,6 & $<0.01$ & $<0.01$ \\
\hline $\mathrm{Na}_{2} \mathrm{O}$ & 3,2 & 0,1 & 0,2 & 0,2 & 0,1 \\
\hline $\mathrm{K}_{2} \mathrm{O}$ & 2,7 & 2,7 & 1,5 & 0,6 & 0,7 \\
\hline $\mathrm{MnO}$ & 0,1 & 0,2 & 0,1 & 0,0 & 0,0 \\
\hline $\mathrm{TiO}_{2}$ & 0,7 & 0,8 & 0,9 & 0,9 & 1,0 \\
\hline $\mathrm{P}_{2} \mathrm{O}_{5}$ & 0,1 & 0,1 & 0,2 & 0,1 & 0,1 \\
\hline $\mathrm{PF}$ & 1,6 & 6,3 & 8,5 & 9,2 & 10,6 \\
\hline Total & 98,9 & 99,6 & 99,8 & 99,5 & 99,4 \\
\hline
\end{tabular}

\begin{tabular}{|c|c|c|c|c|c}
\hline Mi15 & & & & & \\
\hline 68 & 69 & 70 & 71 & 74 & 75 \\
\hline 49 & 45 & 41 & 39 & 25 & 23,9 \\
\hline 29,5 & 86,8 & 85,2 & 60,2 & 55,0 & 41,4 \\
\hline 23,8 & 7,9 & 7,9 & 22,1 & 26,8 & 35,6 \\
\hline 24,6 & 1,1 & 2,2 & 6,1 & 4,3 & 3,3 \\
\hline 0,6 & 0,6 & 0,6 & 0,6 & 0,6 & 0,6 \\
\hline 0,6 & $<0.01$ & $<0.01$ & 0,3 & $<0.01$ & $<0.01$ \\
\hline 0,1 & 0,2 & 0,3 & 0,1 & 0,1 & $<0.02$ \\
\hline 0,3 & 1,9 & 1,4 & 0,7 & 0,4 & 0,5 \\
\hline 0,2 & 0,0 & 0,0 & 0,0 & 0,1 & 0,0 \\
\hline 5,4 & 0,1 & 0,3 & 0,8 & 0,7 & 0,4 \\
\hline 1,0 & 0,0 & 0,0 & 0,1 & 0,2 & 0,1 \\
\hline 12,3 & 1,9 & 2,3 & 8,5 & 11,6 & 17,3 \\
\hline 98,4 & 100,4 & 100,2 & 99,6 & 99,7 & 99,1 \\
\hline
\end{tabular}

Nível topográfico 1710/40m (perfis Mi4c e Mi14)

\begin{tabular}{|c|c|c|c|c|c|c|c|c|c|c|c|c|c|c|c|c|c|c|}
\hline Perfil & Mi4c & & & & & & & & Mi14 & & & & & & & & & \\
\hline Amostra & 23 & 24 & 25 & 27 & 28 & 29 & 30 & 32 & 52 & 54 & 55 & 56 & 57 & 58 & 60 & 62 & 65 & 66 \\
\hline Prof. (m) & 38 & 35,2 & 34 & 31,5 & 30 & 27 & 17 & 1,5 & 42 & 37 & 32,1 & 27 & 24 & 22,5 & 19 & 15 & 3,6 & 1,7 \\
\hline $\mathrm{SiO}_{2}$ & 68,6 & 59,3 & 65,1 & 61,4 & 67,1 & 62,6 & 54,3 & 49,1 & 71,3 & 58,6 & 48,8 & 65,3 & 52,7 & 59,7 & 61,7 & 54,2 & 54,0 & 36,5 \\
\hline $\mathrm{Al}_{2} \mathrm{O}_{3}$ & 16,0 & 20,1 & 20,1 & 20,7 & 19,6 & 20,7 & 25,9 & 24,7 & 14,3 & 23,2 & 30,8 & 19,2 & 26,1 & 23,1 & 22,0 & 25,1 & 28,2 & 37,7 \\
\hline $\mathrm{Fe}_{2} \mathrm{O}_{3}$ & 3,0 & 6,5 & 2,7 & 5,5 & 3,1 & 4,8 & 6,3 & 9,2 & 2,2 & 4,8 & 4,1 & 5,6 & 6,7 & 4,3 & 4,5 & 7,2 & 4,7 & 4,1 \\
\hline $\mathrm{CaO}$ & 1,4 & 0,6 & 0,6 & 0,6 & 0,6 & 0,6 & 0,6 & 0,6 & 1,4 & 0,6 & 0,6 & 0,6 & 0,6 & 0,6 & 0,6 & 0,6 & 0,6 & 0,6 \\
\hline $\mathrm{MgO}$ & 0,9 & 1,6 & 0,6 & 1,1 & 0,4 & 0,0 & $<0.01$ & $<0.01$ & 0,3 & 0,4 & 0,2 & $<0.01$ & $<0.01$ & 0,0 & 0,0 & 0,1 & $<0.01$ & $<0.01$ \\
\hline $\mathrm{Na}_{2} \mathrm{O}$ & 2,0 & 0,4 & 0,4 & 0,4 & 0,3 & 0,1 & 0,3 & 0,5 & 3,1 & 0,6 & 0,0 & 0,4 & 0,5 & 0,2 & 0,2 & 0,1 & 0,4 & 0,2 \\
\hline $\mathrm{K}_{2} \mathrm{O}$ & 4,9 & 2,7 & 3,1 & 2,2 & 1,6 & 1,0 & 0,5 & 0,2 & 6,3 & 2,9 & 1,6 & 0,5 & 1,1 & 1,3 & 1,1 & 1,8 & 0,7 & 0,8 \\
\hline $\mathrm{MnO}$ & 0,0 & 0,1 & 0,0 & 0,1 & 0,0 & 0,0 & 0,0 & 0,0 & 0,0 & 0,0 & 0,0 & 0,0 & 0,0 & 0,0 & 0,1 & 0,0 & 0,0 & 0,0 \\
\hline $\mathrm{TiO}_{2}$ & 0,5 & 0,9 & 0,4 & 0,7 & 0,5 & 0,6 & 0,9 & 0,2 & 0,3 & 0,7 & 0,8 & 1,0 & 1,1 & 0,7 & 0,7 & 1,0 & 0,5 & 0,5 \\
\hline $\mathrm{P}_{2} \mathrm{O}_{5}$ & 0,1 & 0,2 & 0,1 & 0,1 & 0,1 & 0,2 & 0,2 & 0,2 & 0,1 & 0,1 & 0,3 & 0,1 & 0,2 & 0,2 & 0,3 & 0,2 & 0,1 & 0,2 \\
\hline $\mathrm{PF}$ & 2,5 & 7,7 & 6,5 & 7,8 & 7,3 & 9,6 & 10,8 & 13,7 & 0,7 & 8,3 & 11,3 & 7,3 & 10,7 & 10,1 & 8,1 & 8,9 & 10,8 & 18,9 \\
\hline Total & 99,9 & 100,1 & 99,6 & 100,5 & 100,4 & 100,2 & 99,8 & 98,4 & 100,0 & 100,1 & 98,4 & 100,0 & 99,5 & 100,0 & 99,2 & 99,2 & 99,9 & 99,4 \\
\hline
\end{tabular}

Nível topográfico 1800/20m (perfis Mi6b e Mi5b)

\begin{tabular}{c|c|c|c|c|c|c|c|c|}
\hline Perfil & Mi6b & & & & & & & \\
\hline Amostra & 11 & 12 & 13 & 14 & 16 & 19 & 20 & 21 \\
\hline Prof. (m) & 30 & 27 & 25 & 23 & 16 & 6,6 & 4 & 2 \\
\hline $\mathrm{SiO}_{2}$ & 72,9 & 67,7 & 64,9 & 76,3 & 52,0 & 53,6 & 34,5 & 59,3 \\
\hline $\mathrm{Al}_{2} \mathrm{O}_{3}$ & 13,3 & 17,8 & 18,6 & 12,1 & 27,4 & 24,5 & 28,3 & 24,5 \\
\hline $\mathrm{Fe}_{2} \mathrm{O}_{3}$ & 0,0 & 3,0 & 5,3 & 4,1 & 4,7 & 8,3 & 18,3 & 3,8 \\
\hline $\mathrm{CaO}$ & 0,5 & 0,6 & 0,6 & 0,6 & 0,6 & 0,6 & 0,6 & 0,6 \\
\hline $\mathrm{MgO}$ & 0,1 & 0,5 & 0,6 & 0,0 & $<0.01$ & $<0.01$ & 0,1 & $<0.01$ \\
\hline $\mathrm{Na}_{2} \mathrm{O}$ & 1,3 & 0,2 & 0,1 & 0,1 & 0,2 & 0,4 & 0,2 & 0,4 \\
\hline $\mathrm{K}_{2} \mathrm{O}$ & 2,3 & 3,0 & 2,2 & 1,1 & 0,9 & 1,3 & 2,1 & 1,1 \\
\hline $\mathrm{MnO}$ & 0,7 & 0,0 & 0,0 & 0,0 & 0,0 & 0,0 & 0,0 & 0,0 \\
\hline $\mathrm{TiO}$ & 3,9 & 0,3 & 0,8 & 0,7 & 0,7 & 1,3 & 2,5 & 0,5 \\
\hline $\mathrm{P}_{2} \mathrm{O}_{5}$ & 0,3 & 0,1 & 0,1 & 0,1 & 0,1 & 0,1 & 0,2 & 0,1 \\
\hline $\mathrm{PF}$ & 3,0 & 6,7 & 6,4 & 5,1 & 13,0 & 9,8 & 12,2 & 9,6 \\
\hline $\mathrm{Total}$ & 98,3 & 99,9 & 99,5 & 100,1 & 99,7 & 99,8 & 98,9 & 99,9 \\
\hline
\end{tabular}

\begin{tabular}{|c|c|c|c|c|c|c|c|c|c|c|c|c}
\hline Mi5b & & & & & & & & & & & & \\
\hline 33 & 35 & 36 & 37 & 38 & 39 & 41 & 43 & 44 & 45 & 49 & 50 & 51 \\
\hline 46 & 43,5 & 42,2 & 41 & 38 & 37,5 & 32 & 23 & 21 & 18 & 6,5 & 3,5 & 1,5 \\
\hline 48,3 & 67,1 & 70,6 & 84,3 & 82,8 & 72,3 & 52,7 & 28,3 & 37,7 & 56,8 & 46,4 & 39,4 & 35,3 \\
\hline 13,6 & 15,0 & 14,6 & 9,2 & 9,2 & 9,7 & 24,9 & 24,0 & 32,1 & 18,4 & 28,1 & 23,4 & 20,7 \\
\hline 11,2 & 4,0 & 5,4 & 1,7 & 2,5 & 7,7 & 6,0 & 25,3 & 9,2 & 13,2 & 10,9 & 21,2 & 27,1 \\
\hline 12,0 & 1,4 & 0,6 & 0,6 & 0,6 & 0,6 & 0,6 & 0,6 & 0,6 & 0,6 & 0,6 & 0,6 & 0,6 \\
\hline 8,8 & 1,0 & 0,7 & 0,1 & 0,4 & 1,6 & 1,7 & $<0.01$ & 0,3 & $<0.01$ & $<0.01$ & $<0.01$ & $<0.01$ \\
\hline 2,5 & 2,7 & 0,6 & 0,4 & 0,5 & 0,7 & 0,4 & 0,2 & 1,0 & 0,1 & 0,3 & 0,3 & 0,5 \\
\hline 0,6 & 6,8 & 1,2 & 0,5 & 0,6 & 3,3 & 2,0 & 0,3 & 8,4 & 0,6 & 0,0 & 0,0 & 1,0 \\
\hline 0,2 & 0,1 & 0,1 & 0,1 & 0,0 & 0,1 & 0,1 & 0,4 & 0,0 & 0,0 & 0,0 & 0,0 & 0,0 \\
\hline 0,8 & 0,6 & 0,6 & 0,3 & 0,6 & 1,2 & 1,0 & 5,3 & 2,0 & 2,1 & 1,5 & 2,7 & 1,2 \\
\hline 0,1 & 0,1 & 0,1 & 0,1 & 0,1 & 0,2 & 0,3 & 0,6 & 0,1 & 0,1 & 0,2 & 0,4 & 0,2 \\
\hline 1,1 & 1,1 & 5,5 & 3,4 & 3,3 & 3,0 & 9,5 & 14,0 & 6,7 & 7,4 & 11,7 & 11,4 & 13,2 \\
\hline 99,2 & 99,8 & 100,0 & 100,6 & 100,7 & 100,4 & 99,3 & 98,9 & 98,1 & 99,4 & 99,7 & 99,4 & 99,9 \\
\hline
\end{tabular}

(Análises feitas no Instituto de Geociências, USP, Laboratório de Fluorescência de raios-X, dados do equipamento e demais detalhes no texto ou talvez resumidos aqui). 
Tabela 3 - Densidade aparente de amostras de isalterita dos perfis estudados.

Nível topográfico 1640/60m (perfis Mi2b e Mi15)

\begin{tabular}{c|c|c|c|c|c}
\hline Mi2b & LS1 & LS5 & LS6 & LS8 & LS10 \\
\hline Prof. (m) & 48,2 & 29,4 & 26,3 & 19,0 & 3,5 \\
\hline D. A. & 2,6 & 1,9 & 1,7 & 1,9 & 1,8 \\
\hline Mi15 & LS71 & LS75 & \multicolumn{4}{|l}{} \\
\hline Prof. (m) & 39,0 & 23,9 \\
\cline { 1 - 2 } D. A. & 1,9 & 2,0 \\
\cline { 1 - 2 }
\end{tabular}

Nível topográfico 1710/40m (perfis Mi4c e Mi14)

\begin{tabular}{|c|c|c|c|c|c|c|c|c|c|}
\hline $\mathrm{Mi} 4 \mathrm{c}$ & LS23 & LS24 & LS25 & LS27 & LS28 & LS29 & LS30 & & \\
\hline Prof. (m) & 38,0 & 35,2 & 34,2 & 31,5 & 29,9 & 27,0 & 16,8 & & \\
\hline D. A. & 2,3 & 2,0 & 1,9 & 1,8 & 1,7 & 1,8 & 1,9 & & \\
\hline Mi14 & LS52 & LS54 & LS55 & LS56 & LS58 & LS60 & LS62 & LS65 & LS66 \\
\hline Prof. (m) & 42,0 & 37,0 & 32,1 & 27,0 & 22,5 & 19,2 & 15,0 & 3,9 & 1,7 \\
\hline D. A. & 2,6 & 1,6 & 1,7 & 1,0 & 2,0 & 1,6 & 1,5 & 1,7 & 1,7 \\
\hline
\end{tabular}

Nível topográfico 1800/20m (perfis Mi6b e Mi5b)

\begin{tabular}{|c|c|c|c|c|c|c|c|c|c|c|c|c|c|}
\hline Mi6b & LS11 & LS12 & LS13 & LS14 & LS16 & LS19 & LS20 & & & & & & \\
\hline Prof. (m) & 30,0 & 27,0 & 25,0 & 23,0 & 16,0 & 6,6 & 4,0 & & & & & & \\
\hline D. A. & 2,5 & 1,9 & 2,1 & 1,6 & 1,8 & 1,7 & 1,7 & & & & & & \\
\hline Mi5b & LS33 & LS35 & LS36 & LS37 & LS38 & LS39 & LS41 & LS43 & LS44 & LS45 & LS49 & LS50 & LS51 \\
\hline Prof. (m) & 46,0 & 43,5 & 42,2 & 41,0 & 38,0 & 37,5 & 32,0 & 23,0 & 21,0 & 18,0 & 6,5 & 3,5 & 1,5 \\
\hline D. A. & 2,9 & 2,5 & 2,0 & 2,2 & 1,7 & 1,8 & 1,7 & 1,5 & 2,3 & 1,9 & 1,8 & 1,6 & 1,7 \\
\hline
\end{tabular}

(Determinações realizadas no Instituto de Geociências, USP, Laboratório de Geoquímica, pelo método de impermeabilização da amostra com parafina e pesagem em água).
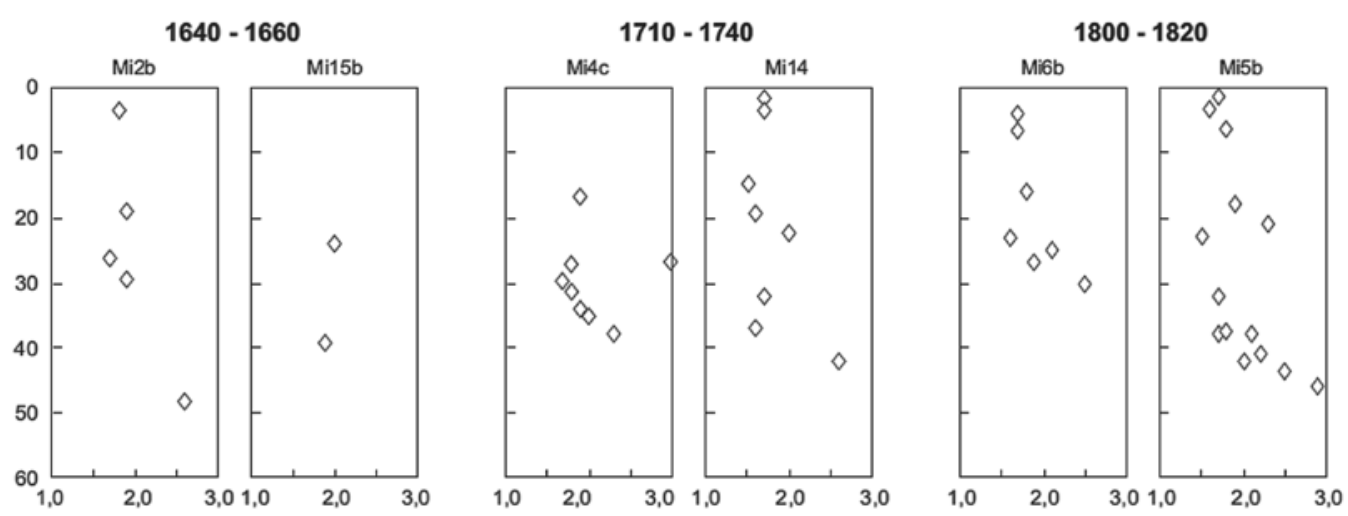

Figura 6 - Gráficos da variação da densidade aparente em amostras dos perfis estudados, mostrando uma diminuição não regular da base para o topo, interpretado pela heterogeneidade dos materiais de origem do intemperismo.

gibbsitizado recuperando as estruturas perdidas.

Nos perfis de alteração não foram encontrados registros indicativos de superposição de tendências de alteração distintas das laterizantes; apenas no solo dos morros mais elevados observa-se uma tendência podzolizante, superposta à laterização, em equilíbrio com as condições atuais de temperatura e umidade (Modenesi 1980, 1983, 1988 b).

É importante destacar que, nos testemunhos recuperados em altitude inferior a $1800 \mathrm{~m}$, a presença de alteromorfos de micas em porções mais rasas sugere truncamento dos perfis de alteração, uma vez que tais ocorrências são típicas das partes intermediária e inferior do manto de intemperismo.

INTEMPERISMO E EVOLUÇÃO DO RELEVO A formação no planalto de Campos do Jordão de um manto de intemperismo com espessura sempre superior a $30 \mathrm{~m}$ e às vezes a $50 \mathrm{~m}$ implica em longo período de tempo e em predomínio das ações de intemperismo sobre as de remoção do material intemperizado. 
Os restos de carapaças alumino-ferruginosas encontrados nos morros mais elevados, in situ e como blocos em linhas de seixos, são testemunho da ação prolongada de importantes e generalizados processos de alitização e ferralitização, que estariam relacionados a ambientes mais quentes, úmidos ou sub-úmidos, anteriores à acentuação do soerguimento do planalto (Modenesi 1980, 1983).

As sondagens evidenciaram a ocorrência de monossiliatização em profundidade, com perfis de evolução intempérica normal, expressa pela alteração progressiva da base ao topo; a sequência de alteração pode, entretanto, ocorrer perturbada por variações da textura e composição mineralógica dos gnaisses. A ausência, no saprólito, de sinais de superposição de ciclos de intemperismo indica permanência da mesma tendência geral laterítica de evolução geoquímica e mineralógica durante todo o processo de formação do manto, porém com fases de diferente intensidade.

A análise dos perfis completos, incluindo materiais superficiais e de sondagem, mostra a existência de duas fases subsequentes de intemperismo laterítico. $\mathrm{Na}$ primeira, mais intensa, feldspato e minerais micáceos são gibbsitizados diretamente (alitização), gerando alteromorfos bem formados. Materiais dessa fase persistem apenas acima de $1800 \mathrm{~m}$, na parte superior dos perfis; testemunham condições agressivas de intemperismo e evidenciam diferença fundamental entre a parte superior $(<1 \mathrm{~m})$ e a parte subjacente do saprólito. Nos materiais de sondagem $(>1 \mathrm{~m})$, predomina a monossialitização, o que representa uma segunda e menos intensa etapa da evolução intempérica. A caolinita pode evoluir em gibbsita por dessilicificação, sem formar alteromorfos. Cabe relembrar que a presença de alteromorfos completos de feldspato nos materiais gibbsíticos superficiais evidencia a gibbsitização direta, pois seria impossível a gibbsita resultar de dessilicificação dos materiais caoliníticos.

Materiais da fase mais antiga de alitização restos de carapaças alumino - ferruginosas encontrados a aproximadamente $1800 \mathrm{~m}$ (L2) e 1900/1920 m (L1) - poderiam refletir a forte tendência laterítica de climas tropicais do Paleoceno / Eoceno, de $59 \mathrm{Ma}$ a $52 \mathrm{Ma}$, período de acentuado aquecimento global (Zachos et al., 2001). Idades um pouco maiores (62 Ma) foram obtidas na parte superior de perfis lateríticos no Quadrilátero Ferrífero (MG), por Spier et al. (2006). As carapaças refletiriam, provavelmente, condições ambientais vigentes imediatamente antes da formação do Rift Continental do Sudeste do Brasil - RCSB (Eoceno/ Oligoceno) (Riccomini 1989), quando o soerguimento do planalto ainda era pequeno.

Materiais da fase de monossialitização refletiriam modificações ambientais introduzidas no planalto pelo aumento da altitude, em conseqüência da acentuação neogênica (Mioceno) do soerguimento ao longo do RCSB (Riccomini 1989, Riccomini et al. 2005). Essas modificações ambientais não mudaram a tendência geral laterítica, mas diminuíram sua intensidade, de alítica (gibbsítica) para monossialítica (caolinítica).
A elevação do planalto a altitudes superiores a $2000 \mathrm{~m}$ favoreceu finalmente a podzolização, nova tendência ajustada às condições ambientais de altitude e observada apenas nos solos (Modenesi 1980, 1983).

Associar os restos de carapaças $\left(\mathrm{L}_{1}\right.$ e $\left.\mathrm{L}_{2}\right)$ a remanescentes de uma superfície de aplainamento anterior à separação dos continentes é difícil, pois, como demonstram dados de termo-cronologia de traços de fissão em apatita referidos por Brown et al. (2000), após esse evento as margens atlânticas da África e da América do Sul sofreram considerável denudação. Também não está claro se as carapaças representam duas fases de intemperismo, relacionadas a diferentes níveis de erosão, ou apenas uma, desenvolvida em topografia ondulada (Valeton et al. 1991).

Dados preliminares de traços de fissão obtidos nas áreas mais elevadas do planalto de Campos do Jordão (Hiruma et al. 2008) indicam idades em torno de $100 \mathrm{Ma}$ (Cretáceo), menores do que as obtidas na serra da Bocaina, geralmente superiores a $200 \mathrm{Ma}$ (Hiruma 2007). Tais idades sugerem que vestígios de uma superfície de erosão pré-cretácea poderiam existir apenas na Bocaina; a superfície cimeira de Campos do Jordão estaria relacionada a evento posterior. Os níveis de erosão de 1710/40 e 1640/60 m relacionar-se-iam provavelmente a processos de denudação mais recentes, plio - pleistocênicos (Modenesi 1980, 1983), que truncaram mais profundamente os velhos perfis lateríticos.

Tendências à gibbsitização ou caolinização identificadas por Modenesi (1980, 1983) nos materiais da parte superior do saprólito foram, na ocasião, atribuídas ao diferente grau de intemperismo dos perfis desenvolvidos, respectivamente, acima e abaixo de $1800 \mathrm{~m}$. A análise do manto em toda a sua profundidade torna evidente que essa dicotomia reflete, na realidade, o truncamento diferencial dos perfis, maior nos dois níveis topográficos inferiores. Evidências de truncamento ocorrem em todos os níveis topográficos, mas especialmente abaixo de $1800 \mathrm{~m}$, onde a erosão expôs zonas menos alteradas do saprólito, caracterizadas pela presença de alteromorfos de minerais micáceos a menor profundidade e por ausência de feições mais avançadas de pedogênese. Acima de $1800 \mathrm{~m}$, predominância de gibbsita e vestígios de carapaças alumino-ferruginosas sugerem menor truncamento, com preservação de restos da parte superior de antigos perfis lateríticos.

Apesar da falta de marcadores estratigráficos no planalto, numerosas evidências morfológicas encontradas ao longo dos lineamentos pré-cambrianos, assim como o alagamento generalizado do setor basal dos anfiteatros de erosão, indicam pelo menos dois pulsos plio-pleistocênicos de soerguimento (Modenesi 1988 a, 1988 b, Modenesi et al. 2002), que correspondem a sinais de deformação regional nos sedimentos do vizinho vale do Paraíba do Sul.

Tentativa de correlacionar as fases de intemperismo com a evolução do relevo resulta em modelo esquemático (Fig. 7) de forma geral coerente com as fases tectônicas reconhecidas por Riccomini (1989) no segmento central do RCSB, exceção apenas da fase holocênica, provavelmente menos marcada no planalto. 
A

$\mathrm{L}_{1}$ mentrismand

II - Eoceno / Oligoceno

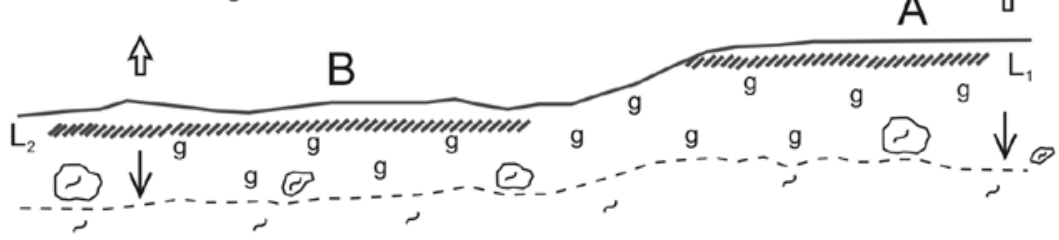

III - Mioceno / Pleistoceno
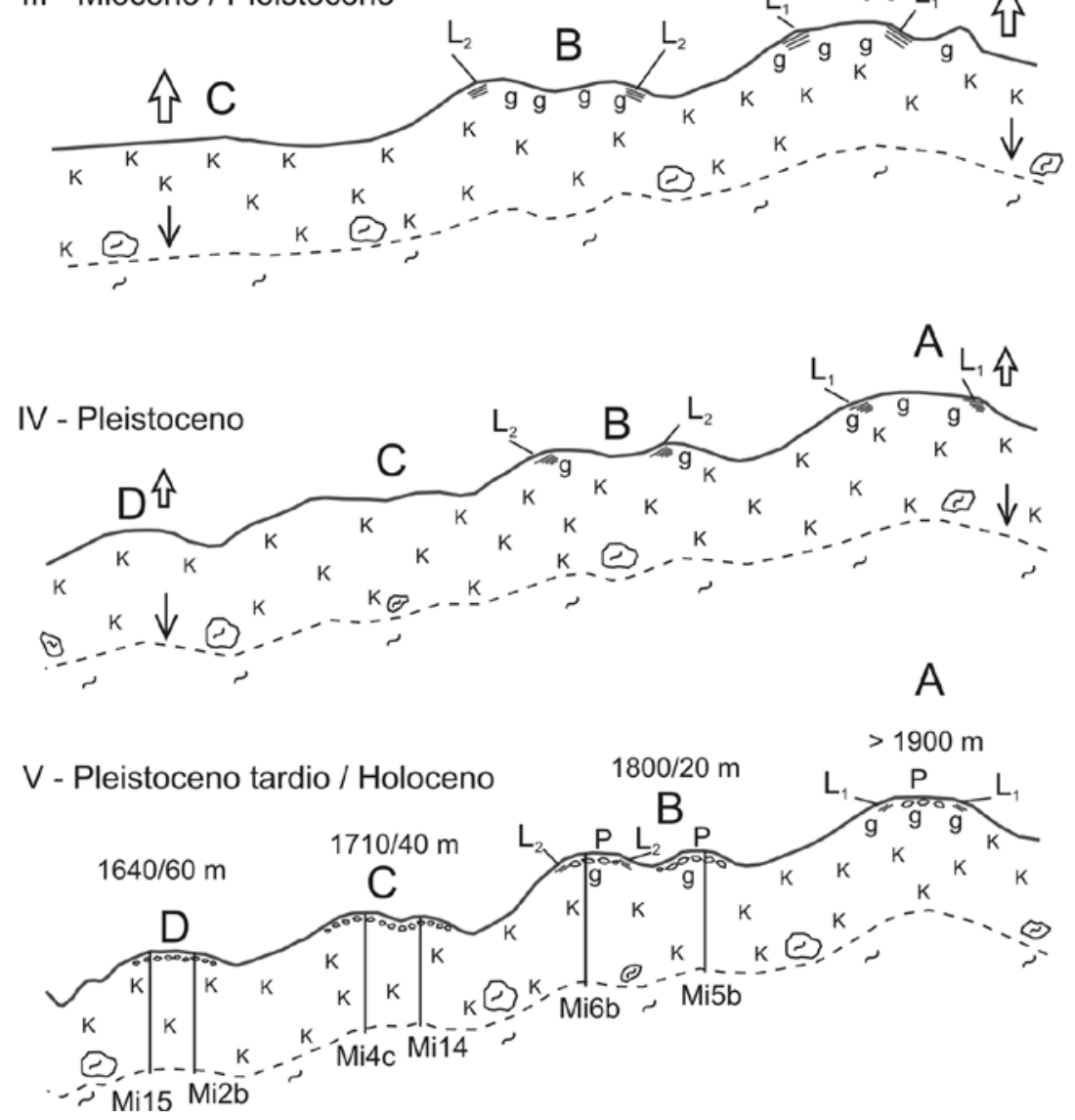

\section{Legenda}

"IIIIII Laterita endurecida

$\mathrm{L}_{1} \quad$ restos de laterita

$L_{2} \quad$ endurecida

... frente de intemperisma

blocos e matacões

个 soerguimento

$\downarrow \quad$ aprofundamento

do intemperismo

gnaisse

g gibbsita

K caolinita

0000 linha de seixos

P podzolização

$\left.\right|_{\text {Misb }}$ perfis

A superficie cimeira

B,C,D níveis escalonados

Figura 7 - Modelo esquemático de correlação entre o intemperismo e a evolução do relevo do planalto de Campos do Jordão. (I) Aquecimento global acentuado; desenvolvimento da superfície cimeira; intemperismo laterítico - alitização com formação direta de gibbsita; lateritas endurecidas L1. (II) Soerguimento do planalto associado à formação do rift continental (RCSB); desenvolvimento do nivel de erosão de 1800 $1820 \mathrm{~m}$; recorrência da alitização e formação de L2. (III) Acentuação do soerguimento; formação do nivel de erosão de 1710-1740 m e truncamento severo dos perfis; o intemperismo profundo segue sob condições ambientais menos agressivas; alitização com fase caolinítica intermediária. (IV) Soerguimento menos acentuado; formação do nivel escalonado inferior, 1640/60 m; ainda, alitização com fase caolinítica. (V) Menor soerguimento, com provável período de calma tectônica no Holoceno (sem evidências de aprofundamento na frente de intemperismo); linhas de seixos e eventos de coluviação relacionados a variações climáticas; acima de $1800 \mathrm{~m}$, tendência podzolizante nos solos. 
Os grandes traços da evolução do relevo do planalto de Campos do Jordão refletem principalmente o ritmo do soerguimento. A alternância de períodos de levantamento e de calma tectônica favoreceu ora os processos erosivos, ora o aprofundamento do manto de intemperismo, em seqüência semelhante a dos modelos tectônicos de áreas intemperizadas (Summerfield 1985, Taylor \& Howard 1998, 1999). O controle do clima foi, provavel- mente, mais ativo durante os períodos de calma tectônica.

Agradecimentos Os autores agradecem à Fundação de Amparo à Pesquisa do Estado de São Paulo FAPESP o apoio financeiro (processo 2003/00203-7) e a Silvio T. Hiruma e Claudio Riccomini, as críticas construtivas.

\section{Referências}

Bisdom E.B.A. 1967. Micromorphology of a weathered granite near the Ria de Arosa (NW Spain).Leidse Geologische Mededelingen, 37:33-67.

Brewer R. 1964. Fabric and mineral analysis of soils. New York, John Wiley, $470 \mathrm{p}$.

Brown R.W., Gallagher K., Gleadow J.W., Summerfield M.A. 2000. Morphotectonic evolution of the South Atlantic margins of Africa and South America. In: Summerfield M.A. (ed.) Geomorphology and global tectonics. John Wiley and Sons Ltd., p. 255-281.

Delvigne J.E.1998. Atlas micromorphology of mineral alteration and weathering. The Canadian Mineralogist, Special Publication, v.3, 494 p.

DEPARTAMENTO NACIONAL PRODUÇÃO MINERAL (DNPM). 1979. Projeto Sapucai - Estados de Minas Gerais e São Paulo. Brasília, DNPM/CPRM, Série Geologia 5, Seção Geologia Básica 2, 299 p.

Hasui Y., Gimenez A.F., Melo M.S. 1978. Sobre as bacias tafrogênicas continentais do sudeste brasileiro. In: SBG, Cong Bras.de Geologia, 30, Recife, Anais, 1:382-392.

Hiruma S.T. 2007. Significado morfotectônico dos planaltos isolados da Bocaina. Tese de Doutoramento, Instituto de Geociências, Universidade de São Paulo, 205 p.

Hiruma S.T., Riccomini C., Modenesi-Gauttieri M.C., Hackspacher P.C., Hadler Neto J.C. 2008. Significado tectônico e denudacional das cimeiras do sudeste do Brasil (Planaltos de Campos do Jordão e da Bocaina). In: SBG, Cong. Bras. de Geologia, 44, Curitiba, Anais, p. 293.

Modenesi M.C. 1980. Intemperismo e morfogênese no planalto de Campos do Jordão. Revista Brasileira de Geociências, 10(3):213-225.

Modenesi M.C. 1983. Weathering and morphogenesis in a tropical plateau. Catena, 10(3):237-251.

Modenesi M.C. 1988a. Quaternary mass movements in a tropical plateau (Campos do Jordão, São Paulo). Z. Geomorphologie N.F., 32(4):425-440.

Modenesi M.C. 1988b. Significado dos depósitos correlativos quaternários em Campos do Jordão - São Paulo: implicações paleoclimáticas e paleoecológicas. São Paulo, Instituto Geológico, Boletim 7, 155 p.

Modenesi-Gauttieri M.C. 2000. Hillslope deposits and the Quaternary evolution of the altos campos - Serra da Mantiqueira, from Campos do Jordão to the Itatiaia Massif. Revista Brasileira de Geociências, 30(3):504-510.

Modenesi-Gauttieri M.C., Hiruma S.T., Riccomini C. 2002. Morphotectonics of a high plateau on the northwestern flank of the Continental Rift of Southeastern Brazil. Geomorphology, 43:257-271.
Morais S.M., Dehler N.M., Sachs L.L.B., Rodrigues J.B. 1998. Carta geológica - Folha Guaratinguetá SF. 23-Y$B$. São Paulo, CPRM /Superintendência Regional de São Paulo, Programa Levantamentos Geológicos Básicos do Brasil, escala 1:250.000.

Oliveira J.B., Menk J.F.R., Rotta C.C. 1975. Solos do Parque Estadual de Campos do Jordão. Revista do Instituto Florestal, 9:125-155.

Riccomini C. 1989. O Rift Continental do Sudeste do Brasil. Tese de Doutoramento, IGc, Univ. de São Paulo, 256 p.

Riccomini C., Sant'Anna L.G., Ferrari A.L. 2005. Evolução geológica do Rift Continental do Sudeste do Brasil. In: Mantesso-Neto V., Bartorelli A, Carneiro C.D.R., Neves B.B.B. (eds.) Geologia do Continente Sul-Americano: evolução da obra de Fernando Flávio Marques de Almeida. São Paulo, Editora Beca, p. 383-405.

Spier C.A., Vasconcelos P.M., Oliveira S.M.B. 2006. ${ }^{40} \mathrm{Ar}{ }^{39} \mathrm{Ar}$ geochronological constranints on the evolution of mlateritic iron deposits in the Quadrilátero Ferrifero, Minas Gerais, Brazil. Chemical Geology, 234(1-2):79104.

Summerfield M.A. 1985. Tectonic background to long-term landform development in tropical África. In: Douglas I. \& Spencer T. (eds.) Environmental change and tropical geomorphology. London, George Allen, p. 281-294.

Taioli F., Modenesi-Gauttieri M.C., Toledo M.C.M., Shimada H. 2005. Levantamentos geoelétricos no planalto de Campos do Jordão, São Paulo, Brasil. In: Geoph. Soc. Congress, $9^{\text {th }}$, Salvador, Expanded Abstracts, p.1-5.

Taylor R.G. \& Howard K.W.F. 1998. Post-Palaeozoic evolution of weathered landsurfaces in Uganda by tectonically controlled deep weathering and stripping. Geomorphology, 25:173-192.

Taylor R.G. \& Howard K.W.F. 1999. Lithological evidence for the evolution of weathered mantles in Uganda by tectonically controlled cycles of deep weathering and stripping. Catena, 35(1):65-94.

Valeton I., Beisser H., Carvalho A. 1991. The tertiary bauxite belt on tectonic uplift areas in the Serra da Mantiqueira, South East Brazil. Contributions to Sedimentology, 17, $101 \mathrm{p}$.

Zachos J., Pagani M., Sloan L., Thomas E., Billups K. 2001. Trends, Rhythms and Aberrations in Global Climate 65 Ma to Present. Science, 292:686-693.

Manuscrito ID 14918

Submetido em 31 de julho de 2009 Aceito em 15 de junho de 2010 